\title{
Predehydration and Ice Seeding in the Presence of Trehalose Enable Cell Cryopreservation
}

\section{Citation}

Huang, Haishui, Gang Zhao, Yuntian Zhang, Jiangsheng Xu, Thomas L. Toth, and Xiaoming He. 2017. "Predehydration and Ice Seeding in the Presence of Trehalose Enable Cell Cryopreservation." ACS Biomaterials Science \& Engineering 3 (8): 1758-1768. doi:10.1021/ acsbiomaterials.7b00201. http://dx.doi.org/10.1021/acsbiomaterials.7b00201.

\section{Published Version}

doi:10.1021/acsbiomaterials.7b00201

\section{Permanent link}

http://nrs.harvard.edu/urn-3:HUL.InstRepos:34375160

\section{Terms of Use}

This article was downloaded from Harvard University's DASH repository, and is made available under the terms and conditions applicable to Other Posted Material, as set forth at http:// nrs.harvard.edu/urn-3:HUL.InstRepos:dash.current.terms-of-use\#LAA

\section{Share Your Story}

The Harvard community has made this article openly available.

Please share how this access benefits you. Submit a story.

\section{Accessibility}




\title{
Predehydration and Ice Seeding in the Presence of Trehalose Enable Cell Cryopreservation
}

\author{
Haishui Huang, ${ }^{\dagger, \$}$ Gang Zhao, ${ }^{\S}$ Yuntian Zhang, ${ }^{\dagger, \S}$ Jiangsheng Xu, ${ }^{\dagger, \|, \perp}$ Thomas L. Toth, \\ and Xiaoming $\mathrm{He}^{*,+, \|, \perp_{\odot}}$
}

\begin{abstract}
${ }^{\dagger}$ Department of Biomedical Engineering, The Ohio State University, 1080 Carmack Road, Columbus, Ohio 43210, United States
${ }^{\ddagger}$ Department of Mechanical Engineering, The Ohio State University, 201 W 19th Avenue, Columbus, Ohio 43210, United States

${ }^{\S}$ Centre for Biomedical Engineering, Department of Electronic Science and Technology, University of Science and Technology of China, 96 Jinzhai Road, Hefei, Anhui 230027, China

"Davis Heart and Lung Research Institute, The Ohio State University, 473 W 12th Avenue, Columbus, Ohio 43210, United States

${ }^{\perp}$ Comprehensive Cancer Center, The Ohio State University, $460 \mathrm{~W}$ 12th Avenue, Columbus, Ohio 43210, United States

"Vincent Department of Obstetrics and Gynecology, Vincent Reproductive Medicine and IVF, Massachusetts General Hospital, 55 Fruit Street, Boston, Massachusetts 02114, United States

$\triangle$ Department of Obstetrics, Gynecology, and Reproductive Biology, Harvard Medical School, 55 Fruit Street, Boston, Massachusetts 02114, United States
\end{abstract}

\section{Supporting Information}

ABSTRACT: Conventional approaches for cell cryopreservation require the use of toxic membrane-penetrating cryoprotective agents (pCPA), which limits the clinical application of cryopreserved cells. Here, we show intentionally induced ice formation at a high subzero temperature $(>-10$ ${ }^{\circ} \mathrm{C}$ ) during cryopreservation, which is often referred to as ice seeding, could result in significant cell injury in the absence of any pCPA. This issue can be mitigated by predehydrating cells using extracellular trehalose to their minimal volume with minimized osmotically active water before

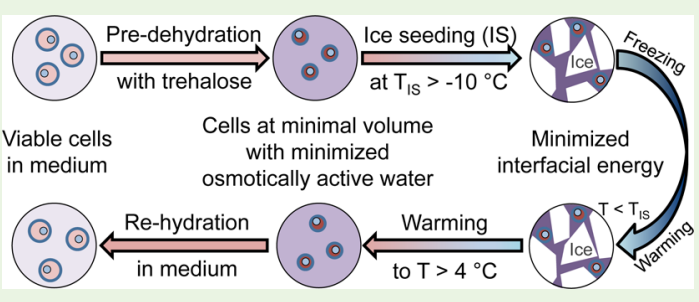
ice seeding. We further observe that ice seeding can minimize the interfacial free energy that drives the devastating ice recrystallization-induced cell injury during warming cryopreserved samples. Indeed, by combining predehydration using extracellular trehalose with ice seeding at high subzero temperatures, high cell viability or recovery is achieved for fibroblasts, adult stem cells, and red blood cells after cryopreservation without using any pCPA. The pCPA-free technology developed in this study may greatly facilitate the long-term storage and ready availability of living cells, tissues, and organs that are of high demand by modern cell-based medicine.

KEYWORDS: osmotically inactive, ice recrystallization, free energy, fibroblasts, stem cells, red blood cells

\section{INTRODUCTION}

Cell cryopreservation is an enabling technology for modern cell-based medicine such as regenerative medicine, organ transplantation (including blood transfusion), and assisted reproduction. ${ }^{1-3}$ It is achieved by cooling cells to a deep subzero temperature (e.g., $-196{ }^{\circ} \mathrm{C}$ ), storing the cells at the low temperature in a state of suspended animation, and warming them back to a supra-zero temperature (e.g., $37^{\circ} \mathrm{C}$ ) for use at the desired time. However, substantial cell injury could occur during the cooling and warming processes. ${ }^{4-7}$

To alleviate the cryoinjury, two conventional approaches have been adopted that require the use of cell membranepenetrating cryoprotectants (pCPAs) such as dimethyl sulfoxide (DMSO) and glycerol: slow freezing and vitrification. ${ }^{8,9}$ For the slow-freezing approach (usually requires 1.5-2 M pCPAs), cells are slowly dehydrated as a result of exosmosis driven by the elevated extracellular osmolality as the extracellular water slowly transforms into ice during freezing at a slow cooling rate (typically less than $5{ }^{\circ} \mathrm{C} \mathrm{min}^{-1}$ ). This allows intracellular water to move across the plasma membrane during freezing at high subzero temperatures $\left(\gtrsim-10{ }^{\circ} \mathrm{C}\right)$ to minimize intracellular ice formation (IIF) during deep freezing. ${ }^{9-11}$ On the other hand, cell vitrification is achieved by cooling cells into an amorphous/vitreous state without ice formation altogether by using a high concentration (up to $\sim 8$ $\mathrm{M})$ of pCPAs and/or an ultrarapid cooling rate, so that water molecules do not have sufficient time to rearrange their positions and orientations for crystallization during cooling. ${ }^{12,13}$

Unfortunately, the pCPAs used by the conventional approaches for cell cryopreservation can cause significant systemic toxicity at $37{ }^{\circ} \mathrm{C}$ and have to be rigorously removed before the cryopreserved cells could be transplanted into

Received: March 31, 2017

Accepted: June 11, 2017

Published: June 12, 2017 
patients. For example, incomplete removal of DMSO from cells has been shown to cause intravascular hemolysis and increased serum transaminase levels in clinic applications. ${ }^{14,15}$ In addition, DMSO has been shown to cause differentiation of more than 25 different human stem cell lines. ${ }^{16}$ Glycerol has been commonly used for cryopreservation of human blood including human red blood cells (hRBCs). ${ }^{17,18}$ However, every one unit of hRBCs cryopreserved with glycerol has to be washed for 30 to $60 \mathrm{~min}$ using a specialized deglycerolization machine to reduce the glycerol concentration to less than $1 \%(\mathrm{w} / \mathrm{v})$ before transfusion. ${ }^{19}$ Moreover, the tedious multistep washing is often associated with significant loss of the precious cells $(\sim 10 \%$ of cell loss during each washing step). ${ }^{20}$

Therefore, efforts have been made to minimize and eventually eliminate the pCPAs for cell cryopreservation. For example, hydroxyethyl starch (HES) at a concentration of 25$40 \%(\mathrm{w} / \mathrm{v})$ has been employed as the sole nonpenetrating cryoprotectant for cryopreserving hRBCs. ${ }^{21,22}$ However, HES could elicit severe side effects including impairment of hemostasis. ${ }^{23,24}$ More recently, several compounds such as poly(vinyl alcohol) (PVA) and phenolicglycosides have been shown to inhibit ice growth during warming and could be used to reduce the pCPA concentration required for cell cryopreservation. ${ }^{2,25,26}$ Trehalose, a nonreducing disaccharide of glucose, has been proposed to be an exceptional cryoprotectant with excellent biocompatibility for cell cryopreservation. $^{27-32}$ Because of its inability to penetrate the cell plasma membrane, current research with trehalose for cell cryopreservation has been focused on either combining it with pCPAs to reduce the pCPA concentration or developing methods to deliver trehalose into cells. ${ }^{20,33-35}$ However, the former could not eliminate the pCPAs and the latter is still elusive today.

Here we report a novel pCPA-free approach for cell cryopreservation using trehalose without the need of intentionally delivering it into cells. This is built upon two observations: (1) ice seeding (including ice nucleation and growth) at a high subzero temperature (e.g., $-4{ }^{\circ} \mathrm{C}$ ) during cooling can release the free energy that drives ice recrystallization (IR) from -30 to $-5{ }^{\circ} \mathrm{C}$ during warming, which prevents the devastating IR-induced cell injury; and (2) predehydration of cells by extracellular trehalose at a nonfreezing (e.g., room) temperature to their minimal volume with minimized osmotically active water can protect the cells from being injured by osmotic shock and IIF during ice seeding in the absence of any pCPA. By combining ice seeding and trehalose predehydration, we accomplished pCPA-free cryopreservation of NIH 3T3 fibroblasts, C3H10T1/2 mesenchymal stem cells, and hRBCs with high viability (or recovery for hRBCs). In fact, a large amount of sugars including trehalose rather than the pCPA and the capability of initiating ice formation at high subzero temperatures have been found in extremophiles that can tolerate extreme cold/freezing in nature. Therefore, this new pCPA-free approach for cell cryopreservation is bioinspired and may greatly facilitate the storage and ready availability of living cells, tissues, and organs to meet their ever-increasing demand by modern cell-based medicine.

\section{MATERIALS AND METHODS}

2.1. Materials. All materials in this study were purchased from Sigma unless specifically mentioned otherwise.

2.2. Cell Culture. NIH $3 \mathrm{~T} 3$ fibroblasts (ATCC, Manassas, VA, USA) and C3H10T1/2 mesenchymal stem cells (ATCC) were cultured in Dulbecco's modified Eagle's medium (DMEM, Invitrogen) supplemented with $10 \%(\mathrm{v} / \mathrm{v})$ fetal bovine serum (FBS, Invitrogen) and $1.1 \%(\mathrm{v} / \mathrm{v})$ penicillin/streptomycin $(\mathrm{P} / \mathrm{S})$ (Hyclone). They were incubated in humidified $5 \% \mathrm{CO}_{2}$ atmosphere at $37{ }^{\circ} \mathrm{C}$. On the day of experiments, cells were detached from culture flasks with trypsin/ ethylenediaminetetraacetic acid (EDTA) (Invitrogen) digestion, centrifuged for $3 \mathrm{~min}$ at $300 \mathrm{~g}$, and resuspended in PBS (or culture medium) for further use. The experimental procedures for C3H10T1/ 2 mesenchymal stem cells are the same as those for NIH 3T3 fibroblasts unless specifically stated otherwise.

2.3. Sample Preparation. Trehalose solutions at twice of the working concentrations were prepared by dissolving the sugar in PBS (or culture medium). Cell suspensions were mixed with the trehalose solutions at a volume ratio of $1: 1$ to suspend cells in solutions of the desired trehalose concentrations (up to $0.65 \mathrm{M}$ depending on the cells) for at least $10 \mathrm{~min}$ until the cell volume did not change. All samples were kept at $4{ }^{\circ} \mathrm{C}$ before further use.

2.4. Cryomicroscopy Study of IIF. Cryomicroscopy studies were performed on a Linkam (Waterfield, UK) FDCS196 freeze-drying stage mounted on an Olympus BX 51 microscope. Real-time images were recorded with a QImaging Retiga CCD color camera. In each experiment, a total of $5 \mu \mathrm{L}$ of cell suspension was loaded into the sample crucible and sandwiched with a glass coverslip $(9 \mathrm{~mm}$ in diameter) to obtain clear images during both cooling and warming. The samples were then cooled to $-80{ }^{\circ} \mathrm{C}$ (or $-130{ }^{\circ} \mathrm{C}$ ) at $60{ }^{\circ} \mathrm{C}$ $\mathrm{min}^{-1}$, held for $2 \mathrm{~min}$, and warmed back to room temperature $\left(22^{\circ} \mathrm{C}\right)$ at $60{ }^{\circ} \mathrm{C} \mathrm{min}{ }^{-1}$. For the scenarios with ice seeding, the samples were cooled to $-4{ }^{\circ} \mathrm{C}$ and held for $2 \mathrm{~min}$, during which ice seeding was done by touching the periphery of the crucible with a stainless steel needle precooled in liquid nitrogen. Ice crystals should nucleate around the deeply cooled spot and further propagate to occupy the entire sample within a flash of second. To check cell viability for the cryomicroscopy studies, we included $5 \mu \mathrm{M}$ of calcein AM (Invitrogen) and $5 \mu \mathrm{M}$ of ethidium homodimer (Invitrogen) in the cell suspensions before cooling to visualize live and dead cells under fluorescence microscopy, respectively.

2.5. Cryopreservation of Eukaryotic Cells. A total of $200 \mu \mathrm{L}$ of the suspension of NIH $3 \mathrm{~T} 3$ fibroblasts or $\mathrm{C} 3 \mathrm{H} 10 \mathrm{~T} 1 / 2$ cells with 0.33 $\mathrm{M}$ trehalose was transferred into a $600 \mu \mathrm{L}$ plastic microcentrifuge tube. After capping, the tube was subsequently submerged into $10 \%(\mathrm{w} / \mathrm{v})$ sodium chloride solution bath maintained at $-4{ }^{\circ} \mathrm{C}$ as monitored by a thermocouple. The cell density was $5-10$ million $\mathrm{mL}^{-1}$ and the total number of cells was 1-2 million. However, the cell density can be decreased and the sample volume can be increased. After incubating/ equilibrating for $5 \mathrm{~min}$, the tube was taken out and touched on its outside wall with a copper wire precooled in liquid nitrogen to seed ice in the cell suspension and then transferred back into the sodium chloride solution bath for equilibration. After holding for $1 \mathrm{~min}$, the tube (attached to a copper coil as the handle) was plunged into liquid nitrogen for further cooling/freezing to $-196{ }^{\circ} \mathrm{C}$. After either $5 \mathrm{~min}$ or $24 \mathrm{~h}$, the tube was taken out of liquid nitrogen and plunged into $37^{\circ} \mathrm{C}$ water bath to warm for $\sim 1 \mathrm{~min}$. The sample temperature after $5 \mathrm{~min}$ of cooling should be similar to that of liquid nitrogen according to the thermal measurements reported in the literature. ${ }^{36,37}$ Finally, $200 \mu \mathrm{L}$ of fresh medium was added into the tube to dilute the cells and trehalose for further examination of cell viability and attachment.

For the conventional cryopreservation of eukaryotic cells, cell suspension with 1.5 M DMSO was added into $1.2 \mathrm{~mL}$ cryovial (Fisher Scientific, USA). Then, the cryovial was transferred into a specially designed slow-freezing container (Bel-Art Products, USA) to cryopreserve the cells according to the manufacturer's instruction: cooling (at $\sim 1{ }^{\circ} \mathrm{C} \min ^{-1}$ ) ${ }^{20}$ the sample in a $-80{ }^{\circ} \mathrm{C}$ freezer overnight, followed by submerging the sample into liquid nitrogen to further cool down to $-196{ }^{\circ} \mathrm{C}$. After $24 \mathrm{~h}$ of storage, the frozen sample was plunged into a $37{ }^{\circ} \mathrm{C}$ water bath for warming. Then, the cell suspension was transferred into $15 \mathrm{~mL}$ centrifuge tube and $10 \mathrm{~mL}$ of fresh medium was added to dilute the DMSO. The tube was centrifuged at $300 \mathrm{~g}$ for $3 \mathrm{~min}$ and the supernatant aspirated to remove most of the DMSO. Finally, $1 \mathrm{~mL}$ of fresh medium was added to resuspend the cells for further analyses. 
a

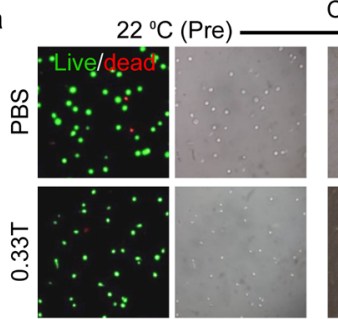

Cooling
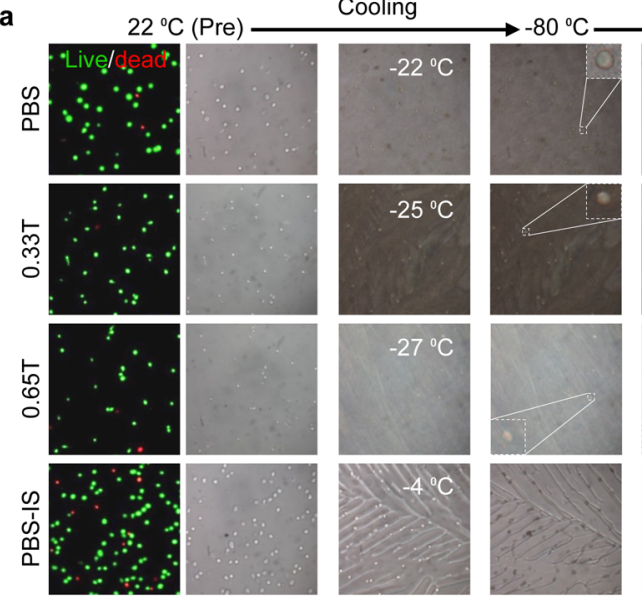

Warming
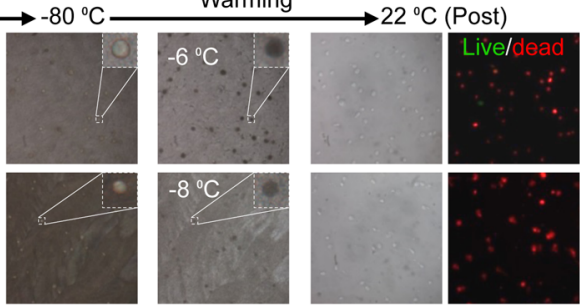

$-27^{\circ} \mathrm{C}$
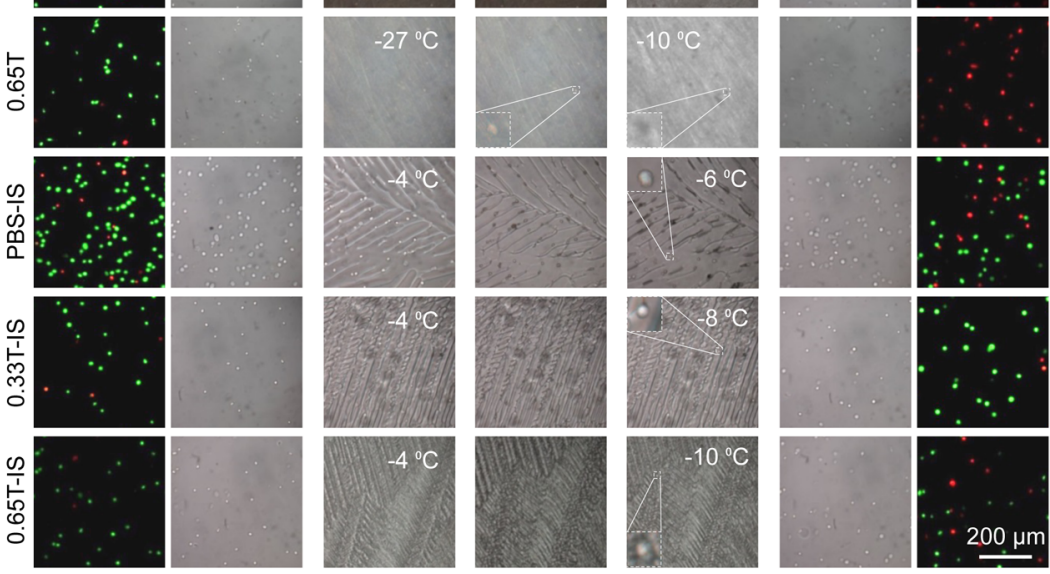

b

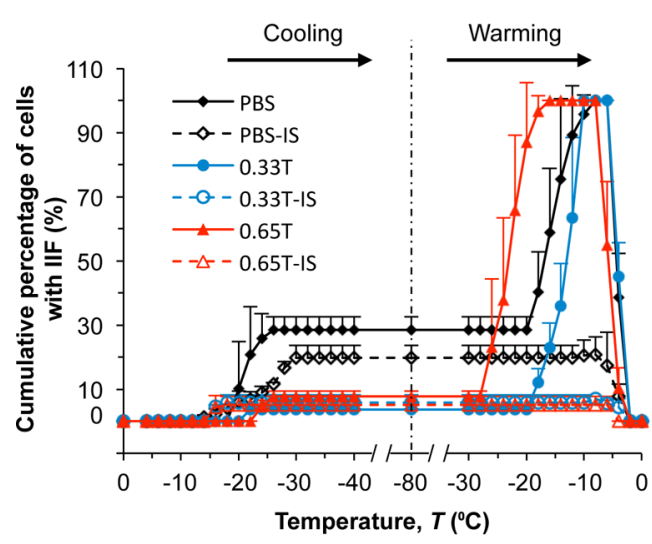

c
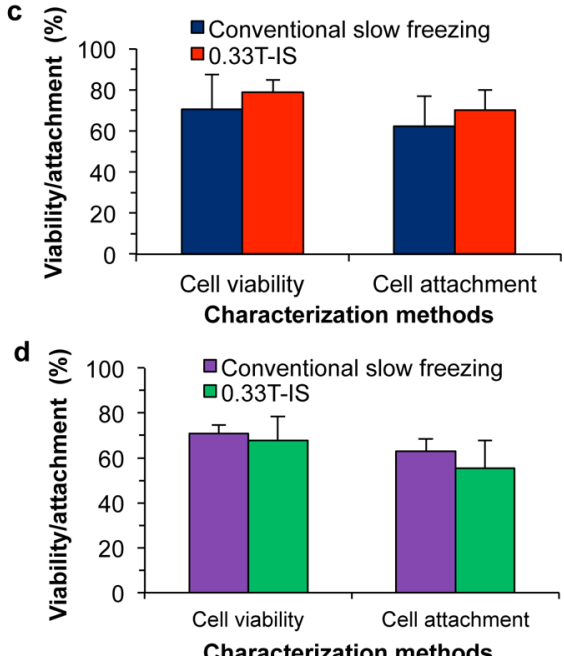

Figure 1. Effect of ice seeding and trehalose predehydration on intracellular ice formation and cell viability. (a) Phase and fluorescence images of NIH 3T3 fibroblasts before cooling, during cooling, and after warming under six different conditions. (b) Cumulative percentage of cells with intracellular ice formation (IIF) quantified using the cryomicroscopy images. "PBS", "0.33T", and "0.65T" represent phosphate-buffered saline, 0.33 $\mathrm{M}$ trehalose solution (in PBS), and $0.65 \mathrm{M}$ trehalose solution (in PBS), respectively. The ice seeding (IS) stands for seeding ice at $-4{ }^{\circ} \mathrm{C}$. "Pre" and "Post" indicate before and after the cooling and warming procedure. The cooling and warming rates were all $60{ }^{\circ} \mathrm{C} \mathrm{min}{ }^{-1}$. (c, d) Viability and attachment of (c) NIH 3T3 fibroblasts and (d) C3H10T1/2 mesenchymal stem cells post cryopreservation using the conventional slow freezing method (with $1.5 \mathrm{M}$ of dimethyl sulfoxide or DMSO) and the pCPA-free approach achieved with predehydration with $0.33 \mathrm{M}$ trehalose at room temperature followed by IS. No significant difference was found between these two methods for cryopreserving these two different types of cells $*: p$ $<0.05$ and $n=4$.

2.6. Cell Viability and Attachment. To assess viability of cells cryopreserved in the microcentrifuge tube, we transferred $50 \mu \mathrm{L}$ of the cell suspension post cryopreservation into another microcentrifuge tube and added $200 \mu \mathrm{L}$ of medium to dilute the cell suspension. Afterward, $1 \mu \mathrm{L}$ of calcein $\mathrm{AM}(1 \mathrm{mM})$ and $1 \mu \mathrm{L}$ of ethidium homodimer $(1 \mathrm{mM})$ were added into the tube and the cells were incubated at $37^{\circ} \mathrm{C}$ for $10 \mathrm{~min}$. The cell suspension was then pipetted onto a $34 \mathrm{~mm}$ plastic dish (forming a flattened drop) for checking viability with fluorescence microscopy (Zeiss Axio Observer.Z1 with $10 \times$ objective). To quantify cell attachment, the cell suspension in one tube post cryopreservation and $1 \mathrm{~mL}$ of culture medium were pipetted into one well in a 6-well plate and cultured in an incubator at $37{ }^{\circ} \mathrm{C}$ with $5 \% \mathrm{CO}_{2}$. The control group was fresh cells of the same quantity from the same batch and cultured in the same 6-well plate. Phase images were taken with a Zeiss Axio Observer.Z1 microscope under a $10 \times$ objective after $20 \mathrm{~h}$ of culture. The supernatant was then removed by aspiration and the cells were washed with PBS before detaching using trypsin/EDTA. Finally, the cell numbers were counted by hemocytometer and the cell attachment was quantified as the ratio of the cell number from experimental group to that of the control group.

2.7. Assessment of Ice Recrystallization in Extracellular Solution. To investigate ice recrystallization (IR) activity in extracellular solution during the warming phase of cryopreservation, we conducted the Splat assay with slight modification to visualize the possible ice growth during annealing., ${ }^{2,38-42}$ Briefly, a total of $5 \mu \mathrm{L}$ of PBS or PBS containing 0.33 M trehalose either with or without ice 
seeding at $-4{ }^{\circ} \mathrm{C}$, was cooled to $-80{ }^{\circ} \mathrm{C}$, and followed by warming back to $-6{ }^{\circ} \mathrm{C}$. The warming and cooling rates were the same as that for cryomicroscopy studies $\left(60{ }^{\circ} \mathrm{C} \mathrm{min}{ }^{-1}\right)$. The samples were then held at $-6{ }^{\circ} \mathrm{C}$ for $15 \mathrm{~min}$ for annealing, during which real-time polarized light microscopy images were taken to track the crystalline changes in size, morphology, and orientation. The ice crystalline parameters including area and circularity were quantified by utilizing ImageJ (version 1.47). The entropy of the polarized light microscopy images of ice crystals was calculated by MATLAB (version R2014a, MathWorks, Natick, MA, USA).

2.8. Effect of Trehalose Predehydration on Cells. For NIH 3T3 fibroblasts, $5 \mu \mathrm{L}$ of coverslip-sandwiched cell suspension (with or without trehalose predehydration) was cooled to $-6{ }^{\circ} \mathrm{C}$, seeded with ice by touch the edge of the sample with a syringe needle precooled in liquid nitrogen, held for $5 \mathrm{~min}$, and warmed back to $22^{\circ} \mathrm{C}$. The choice of $-6^{\circ} \mathrm{C}$ as the ice seeding temperature here is due to the fact that ice seeding at $-6{ }^{\circ} \mathrm{C}$ can dehydrate the cells in PBS to the same degree as predehydration the cells with $0.33 \mathrm{M}$ trehalose at room temperature (to be shown in section 3.4). Cell size and viability were recorded before, during, and after shrinking and cooling. For hRBCs, $100 \mu \mathrm{L}$ of the cell suspension with or without predehydration in $0.33 \mathrm{M}$ of trehalose was cooled to $-6{ }^{\circ} \mathrm{C}$ and seeded with ice. After holding for 5 min, it was warmed back to $22^{\circ} \mathrm{C}$. It was then centrifuged at $1000 \mathrm{~g}$ for 3 min before measuring hemolysis and recovery rates of the hRBCs.

2.9. Preparation and Cryopreservation of hRBCs. Fresh hRBCs were purchased from Zen-Bio (Research Triangle Park, NC, USA) and kept at $4{ }^{\circ} \mathrm{C}$ as stock $\left(\sim 50 \times 10^{6}\right.$ cells per ml $)$. The sample taken from the stock for each experiment was washed to remove the debris of cells lysed during storage, ${ }^{2}$ for which $200 \mu \mathrm{L}$ of PBS was added into $200 \mu \mathrm{L}$ of the blood sample and they were mixed by gentle pipetting. The cell suspension was then centrifuged at $1000 \mathrm{~g}$ for $3 \mathrm{~min}$ and the supernatant aspirated. Next, $1000 \mu \mathrm{L}$ of PBS was added to resuspend the hRBCs. To prepare the hRBCs for cryopreservation, $100 \mu \mathrm{L}$ of trehalose solution (at concentrations twice of the working concentrations) and $100 \mu \mathrm{L}$ of the cell suspension were pipetted into a $600 \mu \mathrm{L}$ microcentrifuge tube to suspend the hRBCs in trehalose solution of the desired concentration. The samples were kept at $4{ }^{\circ} \mathrm{C}$ before and after cryopreservation.

The microcentrifuge tube containing hRBCs was fastened to a copper wire that serves as the handle to move the tube. For samples without ice seeding, the tube was directly plunged into liquid nitrogen and held for $5 \mathrm{~min}$ (our thermal measurements showed that the 200 $\mu \mathrm{L}$ of cell suspension was cooled to $-196{ }^{\circ} \mathrm{C}$ in $30 \mathrm{~s}$ ). Then, it was transferred into a $37{ }^{\circ} \mathrm{C}$ water bath for warming. For samples with ice seeding, the tube containing hRBCs was submerged first into $10 \%$ (w/ v) sodium chloride solution bath at its equilibrium melting point of approximately $-4{ }^{\circ} \mathrm{C}$ for $5 \mathrm{~min}$. Ice seeding was then conducted by touching the outer wall of the tube with a copper wire precooled in liquid nitrogen. Afterward, the tube was transferred back into the sodium chloride solution bath and held there for $1 \mathrm{~min}$ to equilibrate before plunging into liquid nitrogen $(5 \mathrm{~min})$ for cooling and $37{ }^{\circ} \mathrm{C}$ water bath $(1 \mathrm{~min})$ for warming.

2.10. Quantification of Hemolysis and Recovery Rate of hRBCs. After warming, the cell suspension was centrifuged at $1000 \mathrm{~g}$ for $3 \mathrm{~min}$ to collect intact hRBCs and supernatant. Then, $50 \mu \mathrm{L}$ of the supernatant was pipetted into $200 \mu \mathrm{L}$ of deionized water in a micro cuvette so that the absorbance (I) at $450 \mathrm{~nm}$ of the supernatant is within the optimal measurement range of the Beckman Coulter (Brea, CA, USA) Du 800 spectrophotometer and can be determined for assessing the extent of hemolysis and recovery rate. Control groups were the hRBCs in PBS of various trehalose concentrations that were kept at $4{ }^{\circ} \mathrm{C}$ during the whole experimental period without cryopreservation. Samples with $100 \%$ lysis were prepared by suspending the $\mathrm{hRBCs}$ in deionized water, plunging them (in tube) into liquid nitrogen without ice seeding or any cryoprotectants, and warming in $37{ }^{\circ} \mathrm{C}$ water bath, as reported elsewhere. ${ }^{2}$ The hemolysis rate was estimated as $\phi=I / I_{1} \times 100 \%$, where $I_{1}$ is the absorbance of $100 \%$ lysed hRBCs. Therefore, the cell recovery rate can be calculated as $\eta=100 \%-\phi$.
2.11. Statistical Analysis. All data were reported as mean \pm standard deviation (SD) from at least three independent runs. The $p$ value was determined by Student's two-tailed $t$-test using Microsoft Excel to assess statistical significance and $p<0.05$ is taken as statistically significant.

\section{RESULTS}

3.1. Inhibition of IIF during Cooling by Trehalose Predehydration and during Warming by Ice Seeding. Cryomicroscopy studies were conducted to visualize and quantify cells with IIF, a lethal event to cells, during cooling and warming $\mathrm{NIH} 3 \mathrm{~T} 3$ fibroblasts in isotonic (by default) phosphate-buffered saline (PBS) with and without $0.33 \mathrm{M}$ $(0.33 \mathrm{~T})$ or $0.66 \mathrm{M}(0.66 \mathrm{~T})$ trehalose (Figure $1 \mathrm{a}, \mathrm{b})$. Without ice seeding (first three rows in Figure 1a), extracellular ice crystals nucleate stochastically between -20 and $-30{ }^{\circ} \mathrm{C}$ during cooling and propagate throughout the sample instantaneously. Although IIF occurs in only a small portion $(<\sim 30 \%)$ of cells during cooling to $-80^{\circ} \mathrm{C}$ (Figure 1b), almost all cells suffer extensive IIF (manifested as darkened cells $s^{43}$ ) during warming (Figure $1 \mathrm{~b}$ and in the first three rows of Figure 1a) and the cell survival post warming is dismal (Figure 1a and Figure S1) without ice seeding.

More importantly, ice seeding (IS) at $-4{ }^{\circ} \mathrm{C}$ during cooling can dramatically minimize IIF during warming (Figure $1 \mathrm{~b}$ and bright cells in the last three rows of Figure 1a) and improved cell viability ensues (Figure 1a and Figure S1). Furthermore, the inclusion of 0.33 or $0.65 \mathrm{M}$ of trehalose in the extracellular PBS not only dehydrates the cells precryopreservation (first two columns in Figure 1a), but also greatly decreases the probability of IIF during cooling (Figure 1b). As a result, the combination of trehalose predehydration (to minimize IIF during cooling) and ice seeding (to minimize IIF during warming) leads to minimal IIF during the entire cryopreservation procedure (Figure 1a, b) and high cell viability post cryopreservation (Figure 1a and Figure S1). In addition, a trehalose concentration of $0.33 \mathrm{M}$ with ice seeding yields the best cell viability, which is not significantly different from that of control cells without cryopreservation (Figure S1). It is worth noting that PBS was used for the cryomicroscopy studies for best visualization of cells during cooling and warming, but replacing PBS with cell culture medium and further lowering the end temperature during cooling from -80 to $-130{ }^{\circ} \mathrm{C}$ do not compromise the postwarming cell viability $(93.7 \pm 3.9 \%$, Figure S2) when ice seeding and predehydration with $0.33 \mathrm{M}$ trehalose are combined for cooling and warming the cells using the cryomicroscopy system.

3.2. Cryopreservation of Eukaryotic Cells without Any pCPA. The efficacy of cell cryopreservation without any pCPA by combining ice seeding and trehalose predehydration was tested using both NIH 3T3 fibroblasts and $\mathrm{C} 3 \mathrm{H} 10 \mathrm{~T} 1 / 2$ mesenchymal stem cells. After predehydration with $0.33 \mathrm{M}$ trehalose in culture medium in a microcentrifuge tube at room temperature and ice seeding at $-4{ }^{\circ} \mathrm{C}(0.33 \mathrm{~T}-\mathrm{IS})$, the cells $(1-$ 2 millions) in the tube were plunged into liquid nitrogen. The cells were then plunged into $37^{\circ} \mathrm{C}$ water bath for warming. Conventional cryopreservation of the two different types of cells by slow freezing using 1.5 M DMSO as the pCPA was also conducted for comparison. As shown in Figure 1c, the postcryopreservation viability (immediate) and attachment (long-term viability) of the NIH 3T3 fibroblasts are not significantly different between the new pCPA-free approach $(0.33 \mathrm{~T}-\mathrm{IS})$ and the conventional slow-freezing method 
a

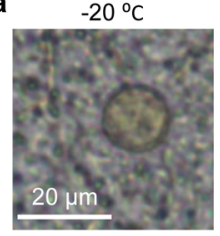

$-15^{\circ} \mathrm{C}$

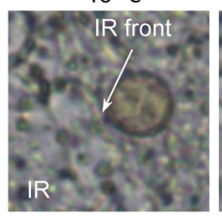

$-12^{\circ} \mathrm{C}$

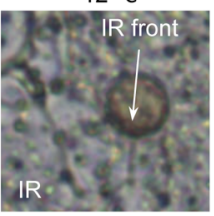

$-10^{\circ} \mathrm{C}$

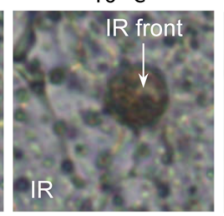

$-8^{\circ} \mathrm{C}$

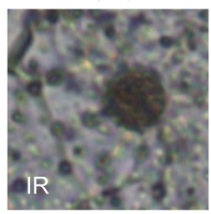

$-6{ }^{\circ} \mathrm{C}$

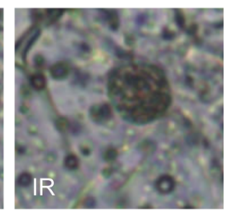

b
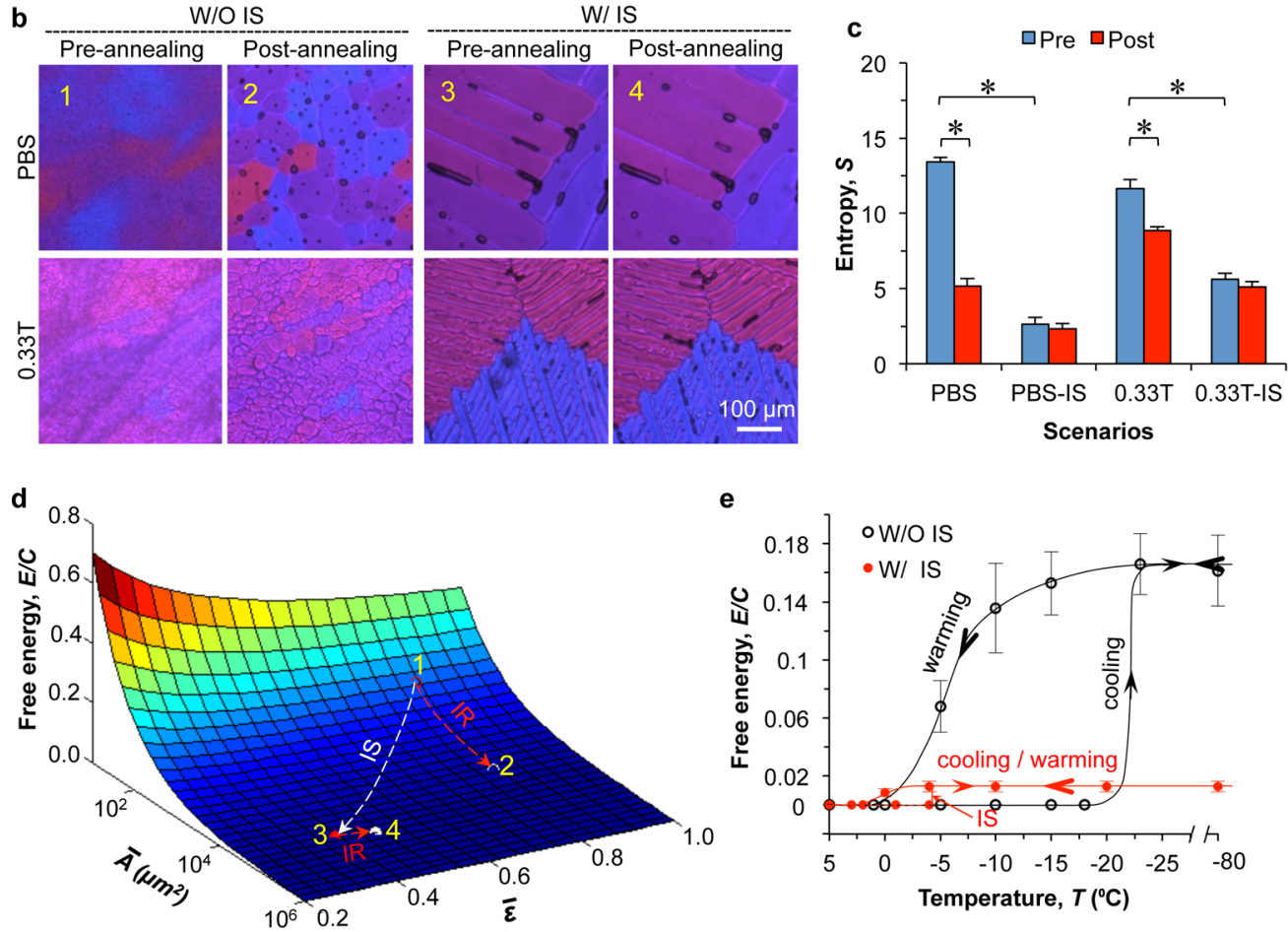

Figure 2. Inhibition of ice recrystallization and associated IIF during warming by ice seeding. (a) Significant IIF induced by extracellular ice recrystallization (IR) during warming observed by real-time cryomicroscopy. (b) Polarized light cryomicroscopy images of ice crystals in PBS and $0.33 \mathrm{M}$ trehalose solution before and after annealing at $-6{ }^{\circ} \mathrm{C}$ for $15 \mathrm{~min}$. (c) Entropy of polarized light cryomicroscopy images of ice crystals in PBS and $0.33 \mathrm{M}$ trehalose solution before and after annealing. (d) Free energy in the PBS sample during cooling and warming showing the effect of ice seeding (IS) on the free energy available for driving IR during warming. $A_{i}$ and $\varepsilon$ are the area and circularity of ice crystals. Points 1,2 , 3 , and 4 correspond to images 1, 2, 3, and 4 in b, respectively. (e) Evolution of free energy during cooling and warming PBS under two different conditions. The equilibrium solution before and after ice melting does not possess free energy that drives IR. "W/" and "W/O" stand for with and without, respectively. $*: p<0.05$ and $n=3$.

requiring 1.5 M DMSO as the pCPA. Representative phase and fluorescence images of the NIH 3T3 fibroblasts shown their immediate viability post cryopreservation are given in Figure S3a, and the typical images showing their attachment after culturing for $20 \mathrm{~h}$ are presented in Figure S3b. Similarly, the viability and attachment of $\mathrm{C} 3 \mathrm{H} 10 \mathrm{~T} 1 / 2$ mesenchymal stem cells cryopreserved with the new pCPA-free approach are not significantly different from that with the conventional slowfreezing approach (Figure 1d and Figure S4). It is worth noting that the storage time ( 5 min versus $24 \mathrm{~h}$ ) in liquid nitrogen does not significantly affect the postcryopreservation viability and attachment of both the fibroblasts and stem cells (Figure S5). This is probably because the sample can be cooled to liquid nitrogen temperature within $2-3$ min (i.e., at $\sim 60-100$ ${ }^{\circ} \mathrm{C} / \mathrm{min}$ ) after plunging into liquid nitrogen, ${ }^{36,37}$ the kinetics of injury is negligible at the liquid nitrogen temperature, $, 9,44$ and cryoinjury mainly occurs during the cooling-down and warming-up phases of a cryopreservation protocol. ${ }^{9,45}$ These results are exciting and further studies are conducted to investigate the mechanisms by which ice seeding and trehalose predehydration inhibit IIF and improve cell survival.
3.3. Inhibition of IR and Associated IIF by Ice Seeding Discerned by Changes in Entropy and Free Energy. Figure la shows that IIF during warming is closely related to ice seeding during cooling. Without ice seeding, the fine ice crystals nucleated between -20 and $-30{ }^{\circ} \mathrm{C}$ during cooling undergo remarkable growth (i.e., IR) during warming, through the formation of more stable crystals at the expense of the dissolution of unstable crystals and/or via self-assembly based aggregation and coalescence by oriented attachment. ${ }^{46,47}$ When the IR front passes through the cell membrane, significant IIF can be triggered as indicated by the darkening spots in Figure $2 \mathrm{a}$ and Movie S1. To the best of our knowledge, this is the first study that provides direct evidence to elucidate the causative link between extracellular IR and IIF during warming.

The aforementioned observations justify the importance of studying extracellular IR during warming and its inhibition by ice seeding at a high subzero temperature. Therefore, annealing at $-6{ }^{\circ} \mathrm{C}$ during warming was conducted to probe the IR inhibition (IRI) mechanism of ice seeding and in situ polarized light microscopy images of frozen PBS with or without trehalose were recorded during the annealing process (Figure 2b). Without ice seeding, the crystal size and crystalline 
a

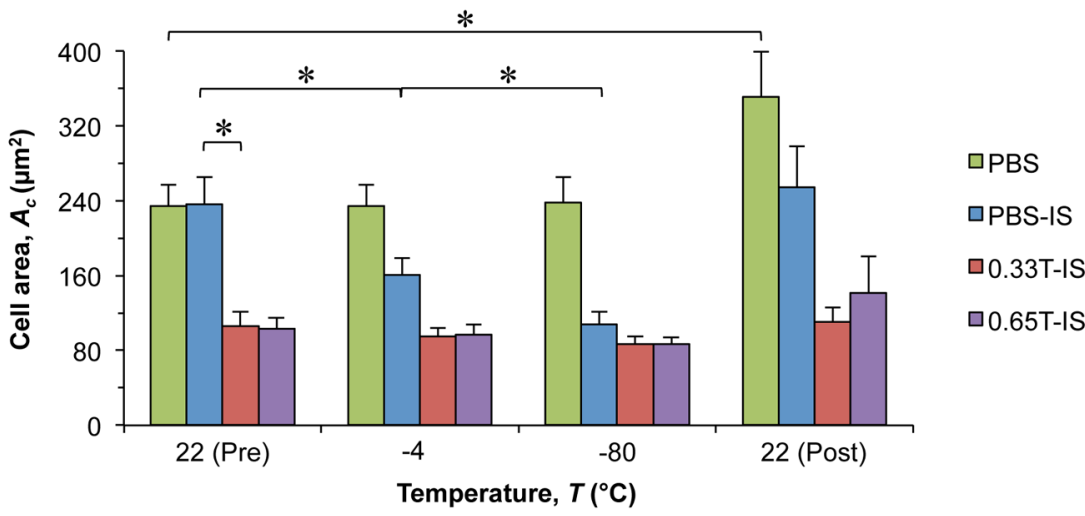

b
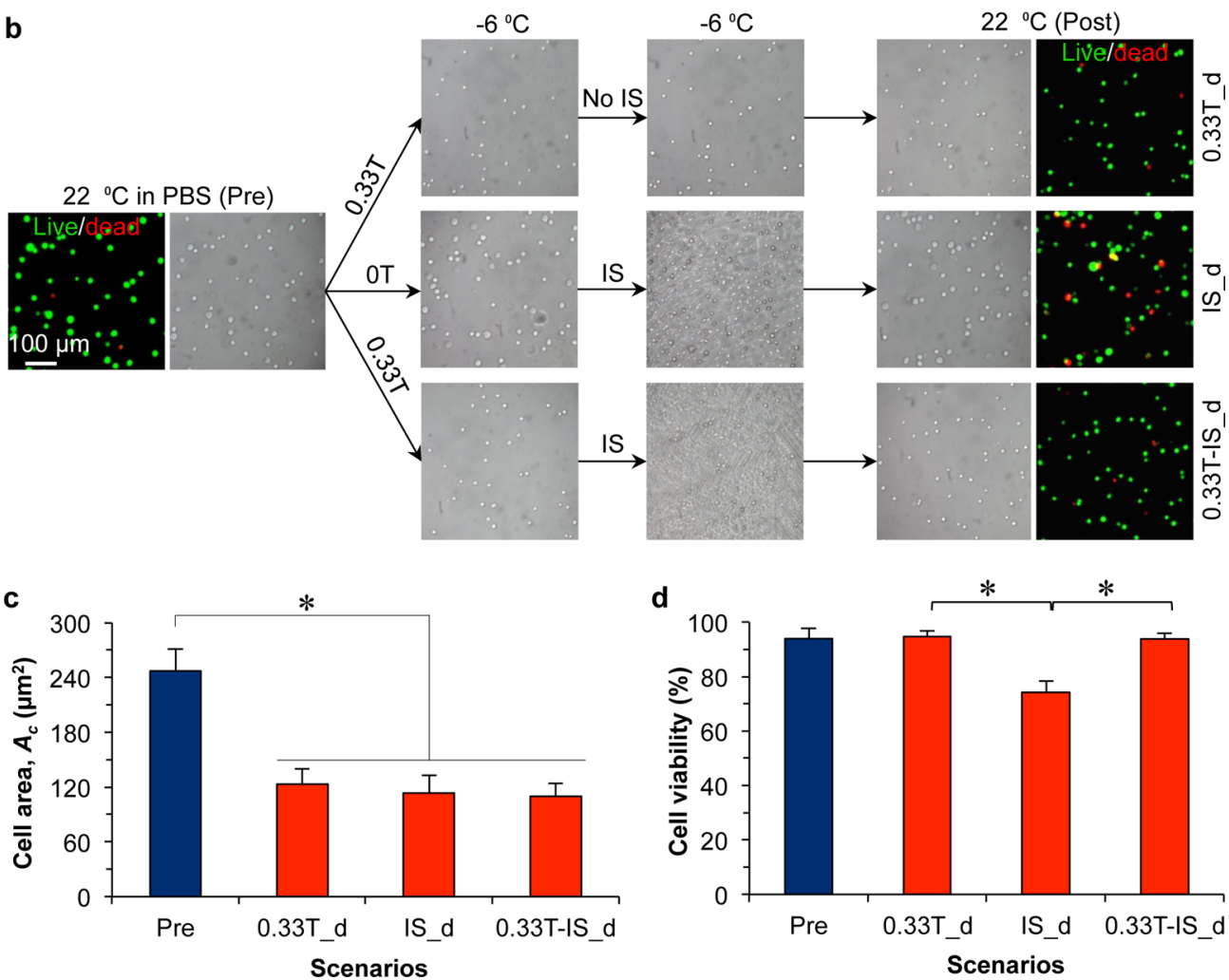

Figure 3. Trehalose predehydration to protect cells from cryoinjury during ice seeding. (a) Area $A_{c}$ of NIH 3 T3 fibroblasts $(n=40)$ determined from cryomicroscopy images. (b) Phase and fluorescence images of the cells after predehydration with $0.33 \mathrm{M}$ trehalose solution at room temperature $\left(22^{\circ} \mathrm{C}\right)$ and/or after dehydration by ice seeding (IS) at $-6{ }^{\circ} \mathrm{C}$. The suffix "d" represents dehydration with trehalose and/or IS without further cooling to below the ice seeding temperature. (c) The corresponding cell area $A_{c}$ before and after dehydration under the conditions shown in b. No significant difference in $A_{c}$ is observed among the three different methods for dehydration. (d) Viability of cells before and after dehydration using the three different methods showing ice seeding-induced injury to cells without trehalose predehydration at room temperature. *: $p<0.05$ and $n=3$.

orientation change drastically with annealing, while they remain almost intact with ice seeding (Figure $2 b$ and Figure S6a) and ice seeding results in serrated ice crystals as indicated by low circularity $\varepsilon$ (Figure S6b). The IR can be described by the entropy $(S)$ change of the polarized light microscopy image of the sample. This is because IR reorganizes the orientation and position of local crystals into a uniform pattern, which decreases the randomness or chaos of ice crystals and the corresponding pixel values. In parallel with thermodynamic entropy that basically determines the IR direction, ${ }^{48}$ image entropy can be calculated as follows: ${ }^{49}$

$$
S=-\sum_{j=1}^{3} \sum_{i=0}^{255} P_{i, j} \log _{2} P_{i, j}
$$

where $P$ is the histogram count of the pixels in the 8 -bit RGB image, $i$ is the gray value of each color channel from 0 (darkest) to 255 (brightest), and $j$ is the color number ( 1 = "red", $2=$ "green", and 3 = "blue"). Because different colors represent different orientations of ice crystals, all the color channels should be included in the calculation of image entropy to evaluate the randomness of crystals. Figure $2 c$ shows that without ice seeding, the entropy plummets after annealing, but with ice seeding, it is greatly reduced and do not vary much 


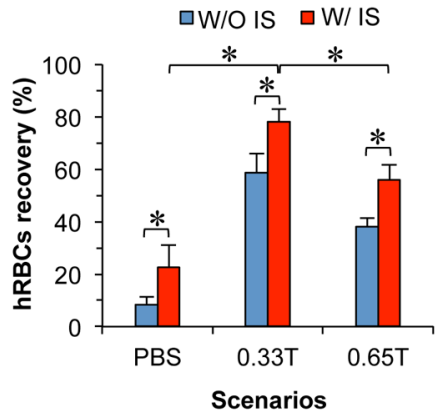

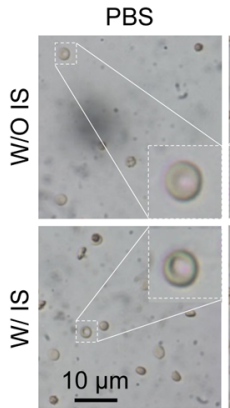

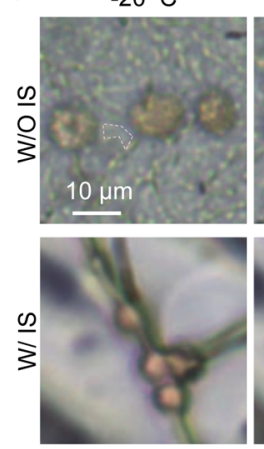

$-12{ }^{\circ} \mathrm{C}$
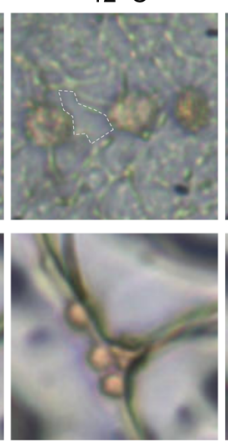

d

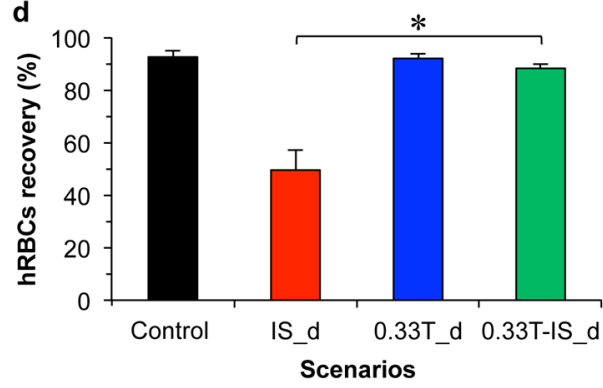

$-6{ }^{\circ} \mathrm{C}$

$-9^{\circ} \mathrm{C}$

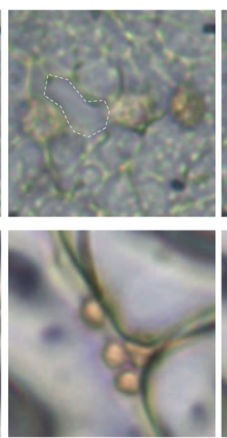

e

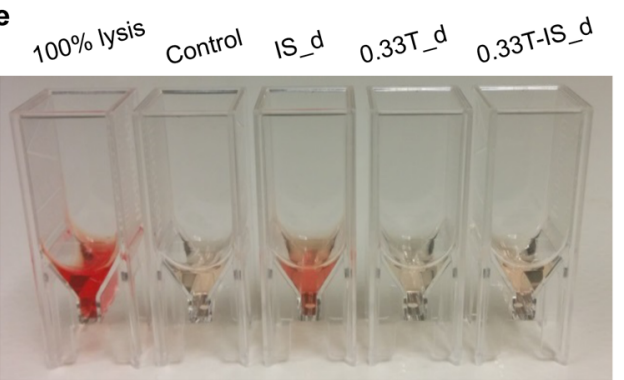

Figure 4. Cryopreservation of human red blood cells without using any pCPA. (a) Recovery rate of human red blood cells (hRBCs) post cryopreservation under six different conditions. (b) Phase images of hRBCs after cryopreservation under the six different conditions. Lower cell density in the images indicates less recovery and more hemolysis. (c) Cryomicroscopy of hRBCs for IR in PBS during warming after cooling to -80 ${ }^{\circ} \mathrm{C}$. The white dashed line encloses a growing ice crystal in each image, which illustrates significant extracellular IR that leads to hemolysis after warming back (e.g., at $2{ }^{\circ} \mathrm{C}$ ). This IR could be effectively inhibited by ice seeding at $-6^{\circ} \mathrm{C}$, although the melting of large ice crystals formed during cooling as a result of ice seeding could also compromise some hRBCs (arrow) after warming. (d) The effect of trehalose predehydration at room temperature on the recovery of hRBCs with and without ice seeding at $-6{ }^{\circ} \mathrm{C}$. "Control" group was cooled to $-6{ }^{\circ} \mathrm{C}$ without any dehydration. (e) The corresponding supernatants collected from samples described in $\mathrm{d}$ and with $100 \%$ lysis. The latter is shown as a negative control. *: $p<0.05$ and $n=4$.

after annealing. Therefore, ice seeding minimizes IR during warming by reducing entropy during cooling.

More comprehensively, IR is due to the general tendency of increasing the crystal size to minimize the interfacial boundary area and overall free energy as a result of interfacial tension in the system. ${ }^{50}$ Given the total sample area $A$ and average ice crystal area $\bar{A}$ in the $2 \mathrm{D}$ cross-sectional images, the number of ice crystals $(N)$ would be

$$
N=A / \bar{A}
$$

The average perimeter of ice crystals $(\bar{l})$ can be related to the $\bar{A}$ and average circularity $(\bar{\varepsilon})$ as follows ${ }^{51}$

$$
\bar{l}=\sqrt{4 \pi \bar{A} / \bar{\varepsilon}}
$$

As IR is mainly driven by interfacial tension between ice crystals and surrounding solution, ${ }^{50}$ the free energy $E$ that drives IR can be expressed as follows

$$
E=\sum_{i=1}^{N} \gamma A_{i}=\sum_{i=1}^{N} \gamma d l_{i}=\sum_{i=1}^{N} l_{i}=\gamma d N \bar{l}
$$

where $\gamma$ is interfacial tension coefficient, $A_{i}$ is the interfacial boundary area of the $i$ th ice crystal, $d$ is the depth or thickness of ice crystals, and $l_{i}$ is the interfacial boundary length or perimeter of $i$ th ice crystal. By combining eqs $2-4, E$ can be formulated as follows

$$
E=2 \gamma d A \sqrt{\pi} / \sqrt{\overline{A \varepsilon}}=C / \sqrt{\overline{A \varepsilon}}
$$

where $C$ can be assumed to be a constant for a given sample. As demonstrated in Figure $2 \mathrm{~d}$, the free energy $E / C$ decreases greatly during ice seeding (Point $1 \rightarrow$ Point 3 in Figure $2 b, d$ ), with minimal change during annealing for IR (Point $3 \rightarrow$ Point 4 in Figure $2 b, d)$. In contrast, without ice seeding, the free energy drops precipitously and drives massive IR during annealing (Point $1 \rightarrow$ Point 2 in Figure 2b, d). Furthermore, 
the overall path of the free energy $E / C$ during cryopreservation is depicted in Figure 2e. Without ice seeding, it demonstrates a giant hysteresis loop with a precipitous rise and fall during cooling and warming, respectively. This hysteresis loop is minimized by ice seeding at $-4{ }^{\circ} \mathrm{C}$ during cooling. In other words, ice seeding at a high subzero temperature can release the enormous free energy that otherwise would be stored in the sample during cooling and released to drive significant IR and IIF during warming.

3.4. Minimizing Cryoinjury during Ice Seeding by Trehalose Predehydration. Although IR and associated IIF during warming can be effectively prevented by ice seeding, nonvitreous cellular cryopreservation is also liable to cryoinjury during ice seeding and further cooling. Figure 1 shows that $\mathrm{NIH} 3 \mathrm{~T} 3$ fibroblasts in PBS suffer more IIF during cooling than the cells with trehalose predehydration, and predehydration with $0.33 \mathrm{M}$ trehalose can significantly augment the cell survival. The cell area $A_{c}$ under top view at various temperatures is plotted in Figure 3a. It can be seen that 0.33 and $0.65 \mathrm{M}$ trehalose can predehydrate the cells to the same extent (Figure S7), and the remaining minimal area or volume is very close the osmotically inactive area or volume. ${ }^{52,53}$ Because predehydration with $0.33 \mathrm{M}$ trehalose has been shown to give the maximum cell survival (Figure 1), we focused on this concentration to illustrate the favorable effect of trehalose predehydration on cells during cooling. As shown in Figure $3 \mathrm{~b}$, $\mathrm{NIH} 3 \mathrm{~T} 3$ fibroblasts were cooled to $-6{ }^{\circ} \mathrm{C}$ in PBS or $0.33 \mathrm{M}$ trehalose either without or with ice seeding, and warmed back to $22{ }^{\circ} \mathrm{C}$. Although ice seeding at $-6{ }^{\circ} \mathrm{C}$ dehydrates the cells to a volume similar to that of predehydration the cells with $0.33 \mathrm{M}$ trehalose (Figure 3c), it significantly lowers the cell viability (Figure 3d). These observations indicate dehydration of cells by freezing at subzero temperatures can cause significant cell injury while the cell injury associated with predehydrating the cells with $0.33 \mathrm{M}$ trehalose at nonfreezing temperature (room temperature here) is minimal. Moreover, predehydration of the cells with $0.33 \mathrm{M}$ trehalose can minimize the cell injury during ice seeding at $-6{ }^{\circ} \mathrm{C}$ to retain a high cell survival after the ice seeding (Figure $3 \mathrm{~d}$ ). Therefore, it can be concluded that the mild trehalose $(0.33 \mathrm{M})$ predehydration at a nonfreezing temperature can protect cells from ice seeding-associated cryoinjury probably due to osmotic shock, IIF, and size change during ice seeding.

3.5. Cryopreservation of hRBCs without any pCPA. Consistent with the cryopreservation of NIH 3T3 fibroblasts and C3H10T1/2 cells, the combination of ice seeding at $-4{ }^{\circ} \mathrm{C}$ and predehydration with $0.33 \mathrm{M}$ trehalose $(12.5 \%, \mathrm{w} / \mathrm{v})$ yields the highest recovery rate $(78.1 \pm 4.8 \%)$ of hRBCs post cryopreservation (Figure $4 \mathrm{a}$ ). This recovery rate outperforms that $(\sim 60 \%)$ of cryopreserving hRBCs with $21.5 \%$ (w/v) HES and $0.1 \%(\mathrm{w} / \mathrm{v})$ PVA $(9 \mathrm{kDa}){ }^{2}$ The hRBCs resuspended in PBS after cryopreservation and the supernatant of the control and cryopreserved samples after centrifugation are shown in Figure $4 \mathrm{~b}$ and Figure S8, respectively. The red appearance in the supernatant of control samples without cryopreservation is minimal while it is visible in the supernatants of $100 \%$ lysed sample and all the samples with cryopreservation. Importantly, the highest density of hRBCs with a normal biconcave discoid morphology (Figure 4b) and least reddish supernatant (Figure S8), indicating the least hemolysis as a result of cryopreservation, are observed for the hRBCs cryopreserved with $0.33 \mathrm{M}$ trehalose and ice seeding. The condition with $0.65 \mathrm{M}$ trehalose is not optimal, again probably due to the excessive osmotic stress imposed by $0.65 \mathrm{M}$ trehalose that can result in damage to the hRBCs as indicated by the crenated morphology for some of the hRBCs in the solution before cryopreservation (Figure S9). In contrast, $0.33 \mathrm{M}$ trehalose can dehydrate hRBCs to their minimal volume with a smooth surface (purple box in Figure S9), which justifies its use for predehydrating the cells.

The protective effect of ice seeding on hRBCs is visualized by cryomicroscopy (Figure 4c). Similar to the NIH 3T3 fibroblasts, hRBCs are subjected to extensive IR (expanding area in the white dashed line) during warming, which could rupture the cell membrane and lyse the hRBCs (Movie S2). More importantly, ice seeding can minimize the IR and associated hemolysis during warming (Movie S3). Notably, the melting of big ice crystals (converting into pure water) formed as a result of ice seeding and the subsequent growth during cooling could generate significant osmolality gradient, which may compromise the plasma membrane to cause hemolysis (black arrow in Figure 4c) and slightly compromise the benefit of ice seeding for cell cryopreservation.

The benefit of using $0.33 \mathrm{M}$ trehalose to predehydrate the hRBCs for cryopreservation is shown in Figure $4 \mathrm{~d}$. Consistent with the NIH $3 \mathrm{~T} 3$ fibroblasts, the recovery rate of hRBCs drops by $\sim 40 \%$ with ice seeding at $-6{ }^{\circ} \mathrm{C}$ in PBS, whereas it is almost unaffected after ice seeding if the cells were preconditioned with $0.33 \mathrm{M}$ trehalose at room temperature. The corresponding supernatant collected after centrifuging the suspensions is shown in Figure 4e. It is worth noting that trehalose predehydration not only can reduce IIF and mitigate cryoinjury during ice seeding as shown in Figures $1 \mathrm{~B}$ and 3, but also can suppress the growth of big ice crystals (Figure $2 \mathrm{~b}$ ) that could induce osmotic gradient and hemolysis during warming the cryopreserved hRBCs.

\section{DISCUSSION}

It is worth noting that this novel pCPA-free approach is fundamentally different from the conventional slow freezing and vitrification methods that require pCPA for cell cryopreservation. In addition, it relinquishes the constraint of slow cooling rate for the conventional slow freezing method, and significantly diverges from the conventional vitrification method because of ice seeding and apparent extracellular ice formation. The former is significant because the samples can be simply plunged into liquid nitrogen after ice seeding, which eliminates the need for any specialized freezing instrument (e.g., the slow-freezing container from Bel-Art Products used in this study for the conventional slow freezing method) and the lengthy procedure associated with the conventional slowfreezing approach for cell cryopreservation. Although ice seeding has been included in the protocol of conventional slow freezing, ${ }^{54,55}$ its main purpose is to nucleate extracellular ice for achieving slow cell dehydration driven by the rising extracellular osmolality as the extracellular ice crystals (formed during ice seeding) grow during the subsequent slow cooling. Cells still contract abruptly during ice seeding at subzero temperature and shrink continually during further cooling, which could induce deleterious stress on the cell membrane for water transport because the viscosity of the freeze-concentrated intra- and extra-cellular solutions skyrockets at freezing temperature, ${ }^{44}$ and could even trigger IIF in some cells (Figure 1b). As a result, a certain amount of $\mathrm{pCPA}$ is required to cushion the freeze concentration-induced osmotic shock and reduce the probability of IIF during ice seeding and the subsequent cooling for the conventional approach. 
In contrast, the main purpose of ice seeding in this study is to inhibit IR during warming. By seeding ice nuclei at a high subzero temperature (e.g., $-4{ }^{\circ} \mathrm{C}$ ) to produce large ice crystals (growing from the seeded ice nuclei) during the subsequent cooling, the free energy available for driving IR during warming (typically between -30 and $-5{ }^{\circ} \mathrm{C}$ ) to form large ice crystals is minimized. This could completely eliminate IR and associated IIF that is lethal to cells. In nature, extremophiles such as freeze-tolerant organisms synthesize a special class of proteins that could decrease the equilibrium temperature of ice formation (i.e., equilibrium freezing point) in water to a few degrees below $0{ }^{\circ} \mathrm{C}$ (which incurs the name of antifreeze proteins or AFPs), ${ }^{56-60}$ However, the AFPs do trigger ice formation at a high subzero temperature, which is similar to ice seeding in this study. Therefore, besides depressing the equilibrium freezing point, freeze-tolerant organisms might synthesize the AFPs for combating the stochastic ice nucleation at deep subzero temperatures and the resultant deleterious IR during warming.

We further found that predehydrating the cells to their minimal volume with minimized osmotically active water using trehalose at room temperature (or any low superzero/ nonfreezing temperature) does not hurt the cells, while significant cell injury does occur during ice seeding that dehydrates the cells to the same degree at a high subzero temperature in the absence of any pCPA. Again, the latter is probably due to the high viscosity of solutions inside and outside the cells that causes significant stress to the cells during dehydration at freezing temperatures. This is supported by the observation that cell injury during ice seeding could be minimized by predehydrating the cells with trehalose at room temperature (Figures 3D, 4D). In addition, trehalose might stabilize the cell plasma membrane during dehydration and rehydration. ${ }^{61-64}$

In nature, small molecular weight sugars including trehalose, sucrose, and glucose have been found in high concentrations in frozen or dry extremophiles that can tolerate extreme cold or dry in nature. ${ }^{27-29,65,66}$ Conventionally, it is hypothesized that the sugars must be present both inside and outside cells for them to protect the cells from cryoinjury, and studies have been focused on developing sophisticated approaches to deliver the sugars into cells. ${ }^{20,33,35,67-70}$ Besides the potential protective effect of the sugars per se, our data suggest that the extremophiles might synthesize the nontoxic sugars to predehydrate their cells before any ice formation to minimize cryoinjury during freezing. Further experimental data are needed to confirm this hypothetical mechanism.

By comparing the data for cell viability or recovery of $\mathrm{NIH}$ 3T3 fibroblasts and hRBCs post cryopreservation, we can infer that cryopreservation of the fibroblasts is more dependent on ice seeding (Figure S1) while hRBCs are more sensitive to trehalose predehydration (Figure 4a). This difference may be interpreted by the difference in cellular structure and property between these two different types of cells. With a complete set of delicate subcellular organelles such as nucleus, Golgi apparatus, and mitochondria, fibroblasts possess a large osmotically inactive volume. This makes them highly susceptible to IR and associated IIF during warming. With regard to hRBCs, the absence of the delicate subcellular organelles makes them less susceptible to IR and associated IIF. Therefore, predehydration with trehalose at room temperature to minimize osmotic shock and IIF during ice seeding and the potential membrane-stabilization effect of trehalose are more important for cryopreserving the hRBCs than fibroblasts. Notwithstanding their different roles for different types of cells, both ice seeding and trehalose predehydration are beneficial and important to achieve high cell viability/recovery post pCPA-free cell cryopreservation.

Moreover, the parameters (i.e., the concentration of trehalose for predehydration and the temperature of ice seeding) of this cryopreservation approach can be optimized according to the biophysical and biochemical properties of a specific cell type to improve the cell recovery. For example, by examining the size of $\mathrm{C} 3 \mathrm{H} 10 \mathrm{~T} 1 / 2$ mesenchymal stem cells after predehydration with various concentrations of trehalose, the optimal trehalose concentration $(0.41 \mathrm{M})$ can be obtained when the cells just shrink to their minimal volume (Figure S10). Therefore, the cell viability and attachment (Figure S11) after cryopreservation can be further improved compared to that (Figure 1d) with predehydration using $0.33 \mathrm{M}$ trehalose $(81.6 \pm 4.9 \%$ versus $67.6 \pm 10.7 \%$ for viability and $68.8 \pm 5.7 \%$ versus $55.4 \pm$ $12.3 \%$ for attachment).

Lastly, our data show that there is no need to intentionally deliver exogenous trehalose inside cells after predehydrating the cells to their minimal volume together with ice seeding in the presence of extracellular trehalose for further cryopreservation. This is possibly because there are various small-molecularweight sugars (e.g., glucose) and large-molecular-weight polymers (e.g., carbohydrates) in cells and the remaining water are bound on these materials, which prevents IIF and associated cell injury during cryopreservation. In other words, these materials may serve as the endogenous intracellular "cryoprotectants". The other possibility is that some extracellular trehalose might leak into the cells during ice seeding and the subsequent freezing as a result of freezing-induced membrane phase transitions, which has been demonstrated in a recent study for fibroblasts. ${ }^{71}$

\section{CONCLUSIONS}

In summary, this study develops a novel pCPA-free approach for cryopreservation of mammalian cells through revealing the unprecedented capability of (1), inhibiting IR during warming by ice seeding at a high subzero temperature, and (2), minimizing cryoinjury during ice seeding and the subsequent cooling by trehalose predehydration of cells to their minimal volume at a low superzero/nonfreezing temperature. Although ice seeding could help to release the free energy required for IR to protect cells from significant IIF or hemolysis during warming, it could induce osmotic shock and IIF. The latter can be overcome by trehalose predehydration of cells at a low superzero/nonfreezing temperature. As a result, the combination of $0.33-0.41 \mathrm{M}$ trehalose for predehydration and ice seeding can yield high cell viability or recovery for fibroblasts, adult stem cells, and hRBCs post cryopreservation without any pCPA. In addition, this combination may mimic the strategy used by freezing-tolerant organisms to combat severe cold and dry in nature. This bioinspired method relinquishes the tedious procedure of pCPA loading and unloading and associated cell damage/loss, a main hurdle to the clinical application of the conventional vitrification and slow freezing approaches for cell cryopreservation. Therefore, it may greatly facilitate the longterm storage and ready availability of living cells, tissues, and organs that are of high demand by modern cell-based medicine. 


\section{ASSOCIATED CONTENT}

\section{S Supporting Information}

The Supporting Information is available free of charge on the ACS Publications website at DOI: 10.1021/acsbiomaterials.7b00201.

Viability of NIH 3T3 fibroblasts after cooling and warming, cryomicroscopy studies of NIH 3T3 fibroblasts cooled to $-130{ }^{\circ} \mathrm{C}$, morphology and viability of $\mathrm{NIH}$ 3T3 fibroblasts and C3H10T1/2 mesenchymal stem cells after cryopreservation, effect of storage time in liquid nitrogen on cell viability and attachment, effect of annealing during warming on the morphology of ice crystals, predehydration of NIH 3T3 fibroblasts, analysis of human red blood cells after cryopreservation without pCPA, predehydration of hRBCs, predehydration of C3H10T1/2 mesenchymal stem cells, cell viability and attachment of $\mathrm{C} 3 \mathrm{H} 10 \mathrm{~T} 1 / 2$ mesenchymal stem cells (PDF)

Movies S1-S3 showing intracellular ice formation or hemolysis induced by extracellular ice recrystallization during warming (ZIP)

\section{AUTHOR INFORMATION}

\section{Corresponding Author}

*E-mail: he.429@osu.edu. Phone: 614-247-8759.

\section{ORCID}

Gang Zhao: 0000-0002-0201-1825

Xiaoming He: 0000-0003-0125-6086

Notes

The authors declare no competing financial interest.

\section{ACKNOWLEDGMENTS}

This work was partially supported by grants from NSF (CBET1605425), NIH (R01EB012108 and R01EB023632), and NSFC (51528601).

\section{REFERENCES}

(1) Blow, N. Biobanking: freezer burn. Nat. Methods 2009, 6 (2), $173-7$.

(2) Deller, R. C.; Vatish, M.; Mitchell, D. A.; Gibson, M. I. Synthetic polymers enable non-vitreous cellular cryopreservation by reducing ice crystal growth during thawing. Nat. Commun. 2014, 5, 3244.

(3) De Vos, M.; Smitz, J.; Woodruff, T. K. Fertility preservation in women with cancer. Lancet 2014, 384 (9950), 1302-10.

(4) Fowler, A.; Toner, M. Cryo-injury and biopreservation. Ann. N. Y. Acad. Sci. 2005, 1066, 119-35.

(5) Gao, D.; Critser, J. K. Mechanisms of cryoinjury in living cells. ILAR J. 2000, 41 (4), 187-96.

(6) Hoffmann, N. E.; Bischof, J. C. The cryobiology of cryosurgical injury. Urology 2002, 60, 40-49.

(7) Gage, A. A.; Baust, J. Mechanisms of tissue injury in cryosurgery. Cryobiology 1998, 37 (3), 171-86.

(8) Pegg, D. E. Principles of cryopreservation. Methods Mol. Biol. 2007, 368, 39-57.

(9) He, X. Thermostability of biological systems: fundamentals, challenges, and quantification. Open Biomed. Eng. J. 2011, 5, 47-73.

(10) Karlsson, J. O. M.; Cravalho, E. G.; Toner, M. A model of diffusion-limited ice growth inside biological cells during freezing. $J$. Appl. Phys. 1994, 75 (9), 4442-4455.

(11) Mazur, P. Freezing of living cells: mechanisms and implications. Am. J. Physiol. 1984, 247 (3Pt 1), C125-142.

(12) Wowk, B. Thermodynamic aspects of vitrification. Cryobiology 2010, 60 (1), 11-22.
(13) Rall, W. F.; Fahy, G. M. Ice-free cryopreservation of mouse embryos at -196 degrees C by vitrification. Nature 1985, 313 (6003), $573-5$.

(14) Davis, J. M.; Rowley, S. D.; Braine, H. G.; Piantadosi, S.; Santos, G. W. Clinical toxicity of cryopreserved bone marrow graft infusion. Blood 1990, 75 (3), 781-786.

(15) Windrum, P.; Morris, T. C. M.; Drake, M. B.; Niederwieser, D.; Ruutu, T.; Par, E. C. L. W. Variation in dimethyl sulfoxide use in stem cell transplantation: a survey of EBMT centres. Bone Marrow Transplant. 2005, 36 (7), 601-603.

(16) Chetty, S.; Pagliuca, F. W.; Honore, C.; Kweudjeu, A.; Rezania, A.; Melton, D. A. A simple tool to improve pluripotent stem cell differentiation. Nat. Methods 2013, 10 (6), 553-6.

(17) Meryman, H. T.; Hornblower, M. A method for freezing and washing red blood cells using a high glycerol concentration. Transfusion 1972, 12 (3), 145-56.

(18) Rowe, A. W.; Eyster, E.; Kellner, A. Liquid nitrogen preservation of red blood cells for transfusion; a low glycerol-rapid freeze procedure. Cryobiology 1968, 5 (2), 119-28.

(19) Cregan, P.; Donegan, E.; Gotelli, G. Hemolytic transfusion reaction following transfusion of frozen and washed autologous red cells. Transfusion 1991, 31 (2), 172-5.

(20) Rao, W.; Huang, H.; Wang, H.; Zhao, S.; Dumbleton, J.; Zhao, G.; He, X. Nanoparticle-mediated intracellular delivery enables cryopreservation of human adipose-derived stem cells using trehalose as the sole cryoprotectant. ACS Appl. Mater. Interfaces 2015, 7, 50175028.

(21) Sputtek, A.; Rau, G. Cryopreservation of human erythrocytes with hydroxyethyl starch (HES)-Part 1: The procedure. Infusionstherapie Transfusionsmedizin 1992, 19 (6), 269-275.

(22) Thomas, M. J.; Parry, E. S.; Nash, S. G.; Bell, S. H. A method for the cryopreservation of red blood cells using hydroxyethyl starch as a cryoprotectant. Transfusion science 1996, 17 (3), 385-96.

(23) Treib, J.; Baron, J. F.; Grauer, M. T.; Strauss, R. G. An international view of hydroxyethyl starches. Intensive Care Med. 1999, 25 (3), 258-68.

(24) Schramko, A. A.; Suojaranta-Ylinen, R. T.; Kuitunen, A. H.; Kukkonen, S. I.; Niemi, T. T. Rapidly degradable hydroxyethyl starch solutions impair blood coagulation after cardiac surgery: a prospective randomized trial. Anesth. Analg. 2009, 108 (1), 30-6.

(25) Capicciotti, C. J.; Kurach, J. D.; Turner, T. R.; Mancini, R. S.; Acker, J. P.; Ben, R. N. Small molecule ice recrystallization inhibitors enable freezing of human red blood cells with reduced glycerol concentrations. Sci. Rep. 2015, 5, 9692.

(26) Wowk, B.; Leitl, E.; Rasch, C. M.; Mesbah-Karimi, N.; Harris, S. B.; Fahy, G. M. Vitrification enhancement by synthetic ice blocking agents. Cryobiology 2000, 40 (3), 228-36.

(27) Crowe, J. H.; Crowe, L. M. Preservation of mammalian cellslearning nature's tricks. Nat. Biotechnol. 2000, 18 (2), 145-6.

(28) Crowe, J. H. Trehalose as a "chemical chaperone": fact and fantasy. Adv. Exp. Med. Biol. 2007, 594, 143-58.

(29) Rothschild, L. J.; Mancinelli, R. L. Life in extreme environments. Nature 2001, 409 (6823), 1092-101.

(30) Cui, X. D.; Gao, D. Y.; Fink, B. F.; Vasconez, H. C.; Pu, L. L. Cryopreservation of human adipose tissues. Cryobiology 2007, 55 (3), 269-78.

(31) Lee, Y. A.; Kim, Y. H.; Kim, B. J.; Kim, B. G.; Kim, K. J.; Auh, J. H.; Schmidt, J. A.; Ryu, B. Y. Cryopreservation in trehalose preserves functional capacity of murine spermatogonial stem cells. PLoS One 2013, 8 (1), e54889.

(32) Pu, L. L.; Cui, X.; Fink, B. F.; Cibull, M. L.; Gao, D. Cryopreservation of adipose tissues: the role of trehalose. Aesthetic Surg. J. 2005, 25 (2), 126-31.

(33) Eroglu, A.; Russo, M. J.; Bieganski, R.; Fowler, A.; Cheley, S.; Bayley, H.; Toner, M. Intracellular trehalose improves the survival of cryopreserved mammalian cells. Nat. Biotechnol. 2000, 18 (2), 163-7.

(34) Eroglu, A.; Toth, T. L.; Toner, M. Small amounts of microinjected trehalose protect mouse and human oocytes during freeze-thaw. Fertil. Steril. 2001, 76 (3), S78-S78. 
(35) Satpathy, G. R.; Torok, Z.; Bali, R.; Dwyre, D. M.; Little, E.; Walker, N. J.; Tablin, F.; Crowe, J. H.; Tsvetkova, N. M. Loading red blood cells with trehalose: a step towards biostabilization. Cryobiology 2004, 49 (2), 123-36.

(36) Jiang, Z.; Zhao, G.; Hossain, S. M. C.; Gao, D. Coupled experimental-modeling analyses of heat transfer in ex-vivo VS55perfused porcine hepatic tissue being plunged in liquid nitrogen for vitreous cryopreservation. Int. J. Heat Mass Transfer 2017, 106, 970979.

(37) Wang, T.; Zhao, G.; Deng, Z.; Gao, C.; Cao, Y.; Gao, D. Theoretical investigation of a novel microwave antenna aided cryovial for rapid and uniform rewarming of frozen cryoprotective agent solutions. Appl. Therm. Eng. 2015, 89, 968-977.

(38) Gibson, M. I.; Barker, C. A.; Spain, S. G.; Albertin, L.; Cameron, N. R. Inhibition of ice crystal growth by synthetic glycopolymers: implications for the rational design of antifreeze glycoprotein mimics. Biomacromolecules 2009, 10 (2), 328-33.

(39) Deller, R. C.; Congdon, T.; Sahid, M. A.; Morgan, M.; Vatish, M.; Mitchell, D. A.; Notman, R.; Gibson, M. I. Ice Recrystallisation Inhibition by Polyols: Comparison of Molecular and Macromolecular Inhibitors and Role of Hydrophobic Units. Biomater. Sci. 2013, 1 (5), $478-485$.

(40) Wharton, D. A.; Wilson, P. W.; Mutch, J. S.; Marshall, C. J.; Lim, M. Recrystallization inhibition assessed by splat cooling and optical recrystallometry. Cryo Lett. 2007, 28 (1), 61-68.

(41) Congdon, T.; Notman, R.; Gibson, M. I. Antifreeze (glyco)protein mimetic behavior of poly(vinyl alcohol): detailed structure ice recrystallization inhibition activity study. Biomacromolecules 2013, 14 (5), 1578-86.

(42) Briard, J. G.; Jahan, S.; Chandran, P.; Allan, D.; Pineault, N.; Ben, R. N. Small-Molecule Ice Recrystallization Inhibitors Improve the PostThaw Function of Hematopoietic Stem and Progenitor Cells. ACS Omega 2016, 1 (5), 1010-1018.

(43) Diller, K. R. Quantitative low temperature optical microscopy of biological systems. J. Microsc. 1982, 126 (1), 9-28.

(44) He, X.; Fowler, A.; Toner, M. Water activity and mobility in solutions of glycerol and small molecular weight sugars: Implication for cryo-and lyopreservation. J. Appl. Phys. 2006, 100 (7), 074702.

(45) $\mathrm{He}, \mathrm{X} . ;$ Bischof, J. C. Quantification of temperature and injury response in thermal therapy and cryosurgery. Crit Rev. Biomed Eng. 2003, 31 (5-6), 355-422.

(46) Banfield, J. F.; Welch, S. A.; Zhang, H.; Ebert, T. T.; Penn, R. L. Aggregation-based crystal growth and microstructure development in natural iron oxyhydroxide biomineralization products. Science 2000, 289 (5480), 751-754.

(47) Li, D.; Nielsen, M. H.; Lee, J. R.; Frandsen, C.; Banfield, J. F.; De Yoreo, J. J. Direction-specific interactions control crystal growth by oriented attachment. Science 2012, 336 (6084), 1014-8.

(48) Kang, J.; Purnell, C. B.; Fisher, N. R. Thermodynamic analysis of intracellular ice recrystallization in mouse oocytes. Cryobiology 2010, $61(1), 166-7$.

(49) Tsai, D. Y.; Lee, Y.; Matsuyama, E. Information entropy measure for evaluation of image quality. Journal of digital imaging 2008, 21 (3), 338-47.

(50) Knight, C. A.; Wen, D.; Laursen, R. A. Nonequilibrium antifreeze peptides and the recrystallization of ice. Cryobiology 1995, 32 (1), 23-34.

(51) Kang, H.; Wen, C.; Hwang, Y.; Shih, Y. R.; Kar, M.; Seo, S. W.; Varghese, S. Biomineralized matrix-assisted osteogenic differentiation of human embryonic stem cells. J. Mater. Chem. B 2014, 2 (34), 56765688 .

(52) Bischof, J. C. Quantitative measurement and prediction of biophysical response during freezing in tissues. Annu. Rev. Biomed. Eng. 2000, 2, 257-88.

(53) Yang, G.; Zhang, A.; Xu, L. X.; He, X. Modeling the cell-type dependence of diffusion-limited intracellular ice nucleation and growth during both vitrification and slow freezing. J. Appl. Phys. 2009, 105 (11), 114701.
(54) Morris, G. J.; Acton, E. Controlled ice nucleation in cryopreservation-a review. Cryobiology 2013, 66 (2), 85-92.

(55) Acker, J. P.; McGann, L. E. Protective effect of intracellular ice during freezing? Cryobiology 2003, 46 (2), 197-202.

(56) Zachariassen, K. E.; Kristiansen, E. Ice nucleation and antinucleation in nature. Cryobiology 2000, 41 (4), 257-79.

(57) Lee, R. E., Jr.; Costanzo, J. P. Biological ice nucleation and ice distribution in cold-hardy ectothermic animals. Annu. Rev. Physiol. 1998, 60, 55-72.

(58) Chapsky, L.; Rubinsky, B. Kinetics of antifreeze protein-induced ice growth inhibition. FEBS Lett. 1997, 412 (1), 241-4.

(59) Bar Dolev, M.; Braslavsky, I.; Davies, P. L. Ice-Binding Proteins and Their Function. Annu. Rev. Biochem. 2016, 85, 515-42.

(60) Storey, K. B.; Storey, J. M. Molecular biology of freezing tolerance. Compr Physiol 2013, 3 (3), 1283-1308.

(61) Leslie, S. B.; Israeli, E.; Lighthart, B.; Crowe, J. H.; Crowe, L. M. Trehalose and sucrose protect both membranes and proteins in intact bacteria during drying. Appl. Environ. Microbiol. 1995, 61 (10), 35923597.

(62) Tang, M.; Waring, A. J.; Hong, M. Trehalose-protected lipid membranes for determining membrane protein structure and insertion. J. Magn. Reson. 2007, 184 (2), 222-7.

(63) Crowe, J. H.; Crowe, L. M.; Wolkers, W. F.; Oliver, A. E.; Ma, X.; Auh, J. H.; Tang, M.; Zhu, S.; Norris, J.; Tablin, F. Stabilization of dry Mammalian cells: lessons from nature. Integr. Comp. Biol. 2005, 45 (5), 810-820.

(64) Gläfke, C.; Akhoondi, M.; Oldenhof, H.; Sieme, H.; Wolkers, W. F. Cryopreservation of platelets using trehalose: the role of membrane phase behavior during freezing. Biotechnol. Prog. 2012, 28 (5), 13471354.

(65) Storey, K. B.; Storey, J. M. Biochemical adaptation for freezing tolerance in the wood frog, Rana sylvatica. J. Comp. Physiol., B 1984, $155,29-36$.

(66) Costanzo, J. P.; Lee, R. E., Jr.; DeVries, A. L.; Wang, T.; Layne, J. R., Jr. Survival mechanisms of vertebrate ectotherms at subfreezing temperatures: applications in cryomedicine. FASEB J. 1995, 9 (5), 351-358.

(67) Wolkers, W. F.; Walker, N. J.; Tablin, F.; Crowe, J. H. Human platelets loaded with trehalose survive freeze-drying. Cryobiology 2001, 42 (2), 79-87.

(68) Chakraborty, N.; Menze, M. A.; Elmoazzen, H.; Vu, H.; Yarmush, M. L.; Hand, S. C.; Toner, M. Trehalose transporter from African chironomid larvae improves desiccation tolerance of Chinese hamster ovary cells. Cryobiology 2012, 64 (2), 91-6.

(69) Chen, T.; Acker, J. P.; Eroglu, A.; Cheley, S.; Bayley, H.; Fowler, A.; Toner, M. Beneficial effect of intracellular trehalose on the membrane integrity of dried mammalian cells. Cryobiology 2001, 43 (2), $168-81$.

(70) Guo, N.; Puhlev, I.; Brown, D. R.; Mansbridge, J.; Levine, F. Trehalose expression confers desiccation tolerance on human cells. Nat. Biotechnol. 2000, 18 (2), 168-71.

(71) Zhang, M.; Oldenhof, H.; Sieme, H.; Wolkers, W. F. Freezinginduced uptake of trehalose into mammalian cells facilitates cryopreservation. Biochim. Biophys. Acta, Biomembr. 2016, 1858 (6), 1400-9. 